\title{
СЕНСОРНЫЕ ТЕХНОЛОГИИ
} МОЛЕКУЛЯРНОЙ ДИАГНОСТИКИ ДЛЯ ПЕРСОНИФИЦИРОВАННОЙ МЕДИЦИНЫ

\section{SENSOR TECHNOLOGY OF MOLECULAR DIAGNOSTICS FOR PERSONALIZED MEDICINE}

\author{
С.Абрамчук* ,А.Ахметова*, Л.Кордюкова*, О.Синицына*, Д.Яминский* , И.Яминский* / yaminsky@nanoscopy.ги \\ S.Abramchuk*, A.Akhmetova*, L.Kordyukova*, O.Sintsyna*, D.Yaminsky*, I.Yaminsky** yaminsky@nanoscopy.ru
}

\begin{abstract}
Важнейшая задача современной медицины состоит в повышении здоровья нации за счет разработки прецизионных методов и аппаратуры раннего обнаружения вирусных и бактериальных патогенов с помощью физических методов с необходимой чувствительностью. К таким методам относятся технологии микрокантилеверных биосенсоров и сканирующей зондовой микроскопии. The most important task of modern medicine is the improvement of the nation's health through the development of precision methods and apparatus for early detection of viral and bacterial pathogens by using physical methods with the required sensitivity. These methods include microcantilever biosensors and scanning probe microscopy.
\end{abstract}

U нфекционные болезни на протяжении многих столетий были и остаются наиболее опасными для человеческого организма из-за их способности поражать большое число здоровых людей в течение короткого периода времени. На протяжении обозримой истории наибольшим бичом для человечества были чума, оспа, холера и желтая лихорадка, которые унесли жизни множества людей.

Совместные усилия врачей многих стран позволили достичь впечатляющих результатов. Число смертных случаев от кори во всем мире уменьшилось с 2,5 млн. в 1983 году до 1,1 млн. в 1992 году, от полиомиелита за тот же период - с 360 тыс. до 140 тыс. Ожидалось, что полиомиелит будет уничтожен в большинстве стран к 1995 году, однако из-за существенного удорожания иммунизации, в странах Юго-Восточной Азии эта инфекция пока не уничтожена. Малярия по-прежнему наносит ощутимый ущерб человечеству, унося из жизни от 1 млн. до 2 млн. людей каждый год.

Несмотря на улучшение условий жизни в экономически развитых странах, широко распространенную практику прививок и наличие эффективных антибиотиков, инфекционные болезни занимают значительное место в структуре заболеваемости и смертности человека, уступая лишь болезням сердечно-сосудистой системы и злокачественным онкологическим заболеваниям. В развивающихся жарких странах из-за плохих санитарных условий и недоедания инфекционные болезни убивают более 10 млн людей каждый год. Большинство смертных случаев среди детей приходятся на инфекционные болезни органов дыхания и кишечника, вызванные вирусами и бактериями. Высокая иммиграция населения из стран "третьего мира" привела в промышленно развитых государствах к резкому увеличению числа лиц, страдающих инфекционными болезнями. При этом, периодически выявляются новые заболевания.

Современный практикующий врач должен уметь грамотно определять тактику диагностики, лечения и противоэпидемических мер. В связи с этим актуальны разработки, обеспечивающие упрощение и ускорение диагностики вирусов, которые позволяют оперативно поставить диагноз пациенту и начать лечение.

Компания "Центр перспективных технологий" и МГУ им. М.В.Ломоносова реализуют проект, нацеленный на дальнейшее развитие высокочувствительных физических методов обнаружения вирусных частиц в воздушной среде и в жидкостях. Разработаны методы, основанные на детек- 
ции вирусов без использования дополнительных меток, что позволяет уменьшить как количество стадий пробоподготовки, так и общее время обнаружения инфекций [1].

Создание высокотехнологичного производства биосенсоров для ранней диагностики позволит выявлять инфекции на ранней стадии всего за 5 мин. Мобильность таких сенсоров упрощает диагностику и дает толчок для развития самодиагностики. В перспективе, при помощи высокоскоростного зондового микроскопа, адаптируя прибор под разные задачи, можно определять небольшие утечки газа, чистоту питьевой воды, массу вируса или бактериальной клетки и даже отдельного атома, обеспечивать контроль лекарств, выявлять допинг и антитела.

В настоящее время развивается лабораторная диагностика вирусных инфекций. Для обнаружения вирусов используются следующие методы:

- электронная микроскопия (рис.1), которая обеспечивает чувствительность на уровне 1 млн. частиц в одном миллилитре, и не всегда позволяет типировать вирусы, а также предполагает использование дорогостоящего оборудования;

- реакция иммунофлуоресценции, которая может успешно применяться для прямой

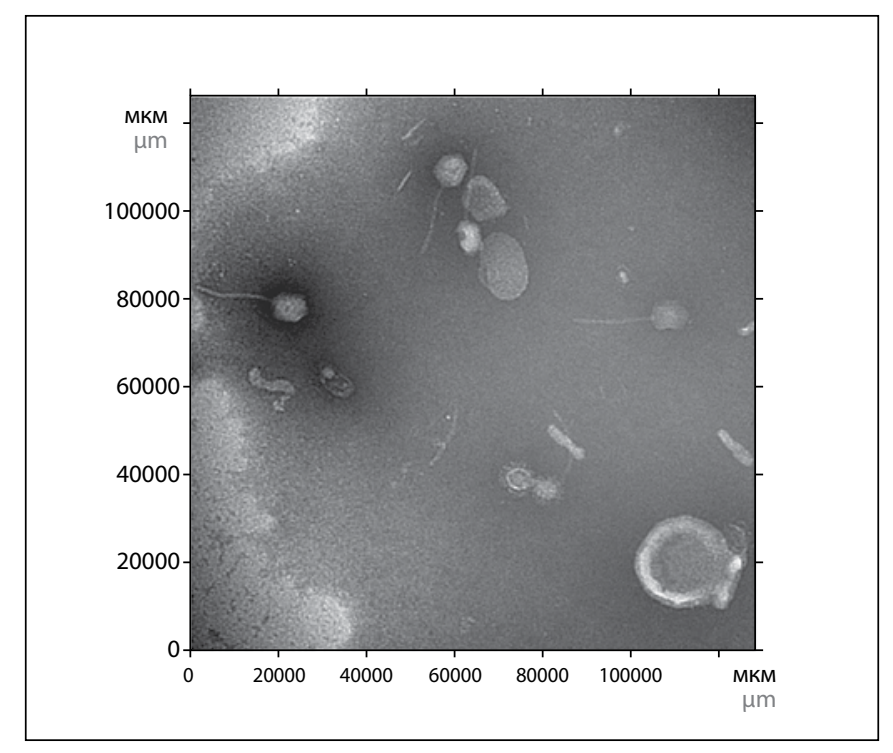

Puc.1. Просвечивающая электронная микроскопия вирусных частиц: бактериофаги (частицы шестигранной формы с нитевидным хвостом) и вирус грunna A/Duck/ Moscow/4182/2008 (частицы округлой формы). Микроскоп Carl Zeiss LEO 912 AB

Fig.1. Transmission electron microscopy of virus particles: bacteriophages (hexagonal particles with a filiform tail) and the influenza virus $A / D u c k / M o s c o w / 4182 / 2008$ (rounded particles). Carl Zeiss LEO 912 AB microscope
I nfectious diseases for many centuries were and still are the most dangerous for the human health because of their ability to affect a large number of healthy people in a short period of time. Throughout history, the greatest scourge of humanity were plague, smallpox, cholera and yellow fever that took the lives of many people.

Joint efforts of physicians from many countries have been helped to achieve impressive results. The number of deaths from measles worldwide has decreased from 2.5 million in 1983 to 1.1 million in 1992, and from polio during the same period - from 360 thou- $^{-}$ sand to 140 thousand. It has been expected that polio will eradicated from most countries by 1995 , however, due to a substantial increase of immunization cost in
South-East Asia this infection is not yet eliminated. Malaria continues to cause significant damage to the mankind, taking of life from 1 million to 2 million people every year.

Despite the improvement of living conditions in economically developed countries, widespread vaccination and effective antibiotics, infectious diseases occupy a significant share of morbidity and mortality, second only to diseases of the cardiovascular system and malignant cancer. In tropical developing countries due to poor sanitary conditions and malnutrition infectious diseases kill over 10 million people per year. The majority of deaths among children is caused by infectious diseases of the respiratory system and intestines. High immigration of people from third world countries has led in industrialized states to a sharp increase in the number of persons suffering from infectious diseases. Thus, new diseases are periodically identified.

The modern medical practitioner must be able to correctly determine the tactics of diagnosis, treatment and epidemic control measures. In this regard, the developments providing simplification and acceleration of virus diagnostics are topical, which will allow promptly to diagnose the patient and start the treatment.

The Advanced Technologies Center and Lomonosov Moscow State University implement a project, aimed at further development of highly sensitive physical methods of detection of virus particles in air and in liquids. The 
детекции вирусов только при содержании в клиническом материале достаточно большого числа инфицированных клеток и незначительной контаминации микроорганизмами, вызываюими неспецифическое свечение;

- иммуноферментный анализ, предполагающий несколько стадий пробоподготовки;

- радиоиммунный анализ, требующий использования радиоактивных веществ и дорогостоящих гамма-счетчиков;

- ПЦР в реальном времени, которая обеспечивает высокую специфичность реакции за счет использования высокоспецифичных флуоресцентных зондов и позволяет проводить количественный анализ;

- реакция торможения гемагглютинации, позволяющая проводить оценку активности вируса, но для нее необходимы клеточные культуры и эритроциты.

Перечисленные методы развиваются, однако их применение в индивидуальных портативных системах затруднено, поскольку все они требуют далеко не компактного лабораторного оборудования.

Задачей раннего обнаружения вирусной инфекции занимается большое число университетов, научных центров и коммерческих компаний. Это обусловлено чрезвычайной важностью решаемой проблемы. Результаты систематического анализа деятельности мировых центров в области диагностики вирусов представлены на сайте http://www.virology.net/garryfavweb.html, где приведен список из более 60 центров в США, Великобритании, Германии, России и других странах. Следуя девизу "Преврати конкурента в эффективного партнера", в рамках российского и международного сотрудничества авторами установлена научная кооперация со следующими организациями: кафедра вирусологии Шотландского научно-исследовательского института урожая, Данди (проф. М.Тальянский); Имперский колледж Лондона (проф. Ю.Корчев); медицинский центр университета Небраски, Омаха (проф. Ю.Любченко); Центр нанотехнологий Вестфальского университета, Мюнстер (проф. Л.Хайнрих); Институт фармацевтической и медицинской химии Вестфальского университета (проф. М.Дюфер); Институт полиомиелита и вирусных энцефалитов, Москва (проф. А.Гамбарян); НИИ гриппа Минздрава РФ, Санкт-Петербург (проф. А.Сомина); НИИ вирусологии, Москва (проф. Ю.Смирнов); кафедра вирусологии МГУ им. М.В.Ломоносова (академик И.Атабеков, проф. О.Карпова); кафедра энзимологии МГУ им. М.В.Ломоносова (академик А.Егоров); Институт биомедицинской химии, Москва (академик А.Арчаков, проф. Ю.Иванов); НИИ физико-химической медицины, Москва (в.н.с. Д.Клинов); LG Electonics, Сеул (д-р К.Квак); Корейский институт науки и технологии, Сеул (д-р С.К.Ким).

Авторы развивают следующие методы обнаружения вирусов в воздушной атмосфере, водной среде и биологических средах: developed methods are based on the detection of viruses without the use of additional marks that can reduce the number of stages of sample preparation and total time for detection of infection [1].

Creation of high-tech production of biosensors for the early diagnosis will help to identify infection at an early stage in 5 minutes. The mobility of such sensors facilitates diagnostics and provides the development of self-diagnostic. In the future it will be possible using a high speed scanning probe microscope, which will adapted for different tasks, to identify a small gas leak, purity of drinking water, a mass of virus or bacterial cells, or even of a single atom, as well as to provide control of drugs, and to identify doping and antibodies.

Currently, laboratory diagnosis of viral infections is developing. The following methods are used for virus detection:

- electron microscopy (fig.1), which provides a sensitivity about 1 million particles per ml., not always allows to type viruses, and also involves the use of expensive equipment;

- reaction of immunofluorescence that can be successfully applied for direct detection of viruses only if clinical material contains a sufficiently large number of infected cells, and in the case of slight contamination by microorganisms that cause non-specific luminescence;

- enzyme-linked immunosorbent assay, involving several stages of sample preparation;

- radioimmunoassay analysis, requiring the use of radioac tive substances and expensive gamma counters;

- in real-time PCR, which provides high specificity of reac tions due to the use of highly specific fluorescent probes 


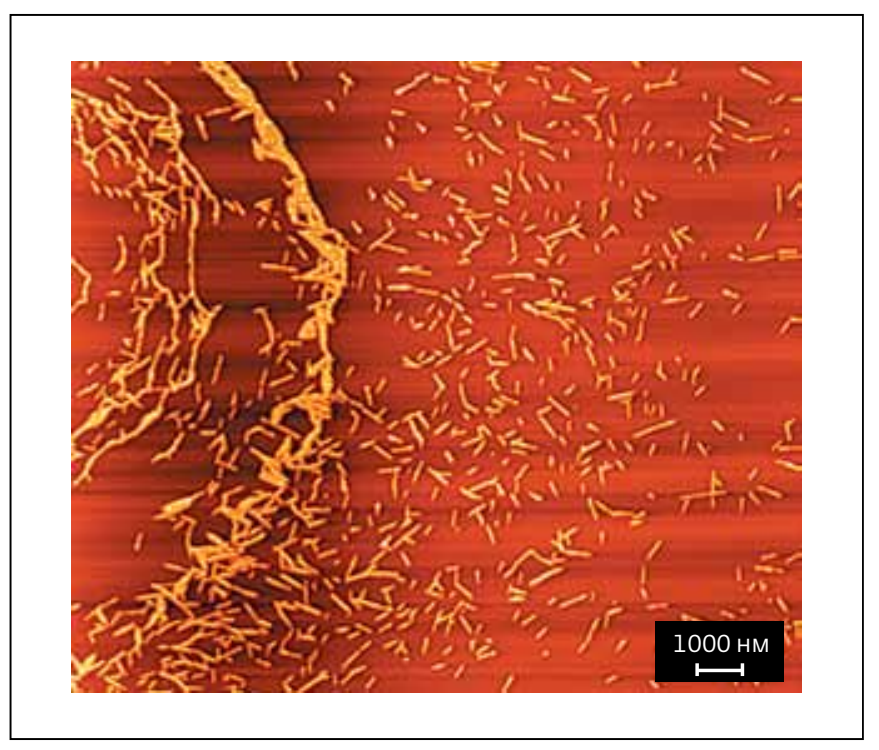

Pис. 2. Изображение вируса табачной мозаики на поверхности слюды, полученное в режиме атомно-силовой микроскопии на зондовом микроскопе "ФемтоСкан" (Центр перспективных технологий)

Fig.2. AFM image of tobacco mosaic virus on mica surface. FemtoScan scanning probe microscope (Advanced Technologies Center)

- сканирующая зондовая микроскопия;

- высокодобротные механические резонаторы;

- современные высокочувствительные камеры. Сканирующая зондовая микроскопия перспективна в качестве инструмента прямой визуализации сорбции вирусов на сенсор- ных поверхностях (рис.2). При этом могут быть усовершенствованы режимы измерений для уменьшения воздействия со стороны зонда на исследуемые объекты. Сверхскоростная сканирующая микроскопия с использованием видеорежима при частоте выборки в 1 МГц позволяет существенно сократить время измерений. Зондовая микроскопия перспективна как метрологическое средство контроля всех стадий изготовления биосенсорного элемента, а также для оценки работоспособности такого элемента при проведении экспериментальных измерений. Дополнительный контроль качества биосенсорного элемента проводится методами сканирующей и электронной микроскопии.

Высокодобротные механические резонаторы являются перспективными системами для измерения присоединенной массы при адсорбции вирусов, а также для регистрации изменения поверхностной жесткости рецепторного слоя при установлении биоспецифического взаимодействия между гемагглютинином вируса и сиаловыми кислотами, расположенными на поверхности биосенсорного элемента [1]. Уже разработана аппаратура атомных весов, которая в модельных экспериментах позволяет проводить регистрацию прикрепленной массы на воздухе (или вакууме) на уровне 10 аттограмм. Масса вируса гриппа А примерно в 500-100 раз больше. Однако, детекцию вирусных частиц надо проводить в жидких средах, что существенно (на несколько порядков) пони- and allows the quantitative analysis;

- hemagglutination assay, which allows to evaluate the activity of the virus, but requires cell culture and erythrocytes.

These methods are developed, but their application in portable systems is difficult because they all require not compact laboratory equipment.

A large number of universities, research centers and commercial companies explores the problem of early detection of viral infection, because it is extremely important. The results of the systematic analysis of activity of the world centers in the field of diagnostics of viruses are presented on the website http://www.virology.net/garryfavweb.html featuring the list of more than 60 centers in the US, the UK, Germany, Russia and other countries. Following the motto "Turn a competitor into an effective partner", the authors have established scientific cooperation with the following domestic and international organizations: Virology Department at the Scottish Crop Research Institute, Dundee (Prof. M.Taliansky); Imperial Colledge London (Prof Yu. Korchev); University of Nebraska Medical Center (Prof. Yu. Lyubchenko);
Center of Nanotechnology, Muenster (Prof. L. Heinrich); Institute of Pharmaceutical and Medicinal Chemistry, Muenster (Prof. Martina Duefer); Institute of Poliomyelitis and Viral Encephalitides, Moscow (Prof. A.Gambaryan); Research Institute of Influenza, St. Petersburg (Prof. A.Somina); Institute of Virology, Moscow (prof. Yu.Smirnov); the Department of Virology of Lomonosov Moscow State University (Academician I.Atabekov, Prof. O.Karpova); Department of Enzymology of Lomonosov Moscow State University (Academician A.Egorov); 
жает чувствительность измерения прикрепленной массы. В результате, при имеющейся геометрии механического микрорезонатора необходимая чувствительность не достигается. Для ее повышения по обнаружению вирусов в жидких средах нами выработано решение по миниатюризации микрорезонатора с возбуждением продольных и/или поверхностных мод колебаний, демпфирование которых в жидких средах незначительно [2].

Современные высокочувствительные камеры позволяют регистрировать релеевское рассеяние от одиночных вирусных частиц, что дает возможность следить за их положением в пространстве и записывать траекторию их движения.

В созданной авторами новой лабораторной установке для медицинской диагностики совмещены все три метода: зондовая микроскопия, микрорезонаторная регистрация и релеевское рассеяние от вирусных частиц в единый измерительный комплекс с уникальными возможностями по многопараметрическому изучению кинетики сорбции вирусов.

Авторы выражают благодарность Российскому фонду фундаментальных исследований за поддержку (проект 15-407678).

\section{ЛИТЕРАТУРА}

1. Gorelkin P.V., Erofeev A.S., Kiselev G.A., Kolesov D.V., Dubrovin E.V. Yaminsky I.V. // Synthetic sialylglycopolymer receptor for virus detection using cantilever-based sensors // Analyst. 2015 (140). PP. 6131-6137.

2. Киселев Г., Горелкин П., Ерофеев А., Колесов Д., Яминский И. // Детекция вирусов с помощью пьезоэлектрических кантилеверов // Наноиндустрия. 2015. № 4(58). С. 62-67.
Institute of Biomedical Chemistry, Moscow (Academician A.Archakov, Prof. Yu.Ivanov); SRI of PhysicalChemical Medicine, Moscow (leading researcher D.Klinov); LG Electonics, Seoul, South Korea (Dr. K.Kwak); Korean Institute of Science and Technology, Seoul, South Korea (Dr. Sang Kyung Kim).

The authors develop the following methods of virus detection in air atmosphere, the aquatic environment and biological media:

- scanning probe microscopy;

- high-Q mechanical resonators;

- modern high-sensitivity camera.

Scanning probe microscopy as a promising tool for direct visualization of virus sorption on sensor surfaces (fig.2). Besides, the measurement modes can be improved to reduce the impact of the probe on the investigated objects. Ultrafast scanning microscopy using video mode at the sampling rate of $1 \mathrm{MHz}$ can significantly reduce measurement time. Probe microscopy is a promising metrological tool to control all stages of manufacturing of biosensor element, and also to evaluate the operability of this element in experimental measurements. An additional quality control of biosensor element is carried out using scanning and electron microscopy.

High-Q mechanical resonators are promising systems for the measurement of attached mass by virus adsorption, and for registration of changes in the surface hardness of the receptor layer during biospecific interaction between the virus hemagglutinin and sialic acids located on the surface of the biosensor element [1]. The atomic scale is already developed, which allows in model experiments the registration of the attached mass in air (or vacuum) at the level of $10 \mathrm{ag}$. The mass of influenza A virus is about 500-100 times greater. However, the detection of viral particles must be carried out in liquids, which significantly (several orders of magnitude) reduces the sensitivity of the measurement of attached mass. As a result, required sensitivity is not achieved by existing geometry of the mechanical microresonator. To increase the sensitivity of the detection of viruses in liquid media, we have developed a solution for miniaturization of the microresonator with the excitation of longitudinal and/or sur face modes of oscillations, which damping in liquid media is insignificantly [2].

Modern high-sensitivity cameras allow to record the Rayleigh scattering caused by single virus particles, which allows to monitor their position in space and to record the trajectory of their movement.

The authors have created a new laboratory device for medical diagnostics, which combines all three methods (scanning probe microscopy, microresonators registration and Rayleigh scattering from virus particles) in a single measurement system with the unique capability of multiparameter study of sorption kinetics of virus.

The authors thank the Russian Foundation for basic research for support (project 15-4-07678). 